Article DOI: https://doi.org/10.35219/history.2017.06

\title{
Oana-Maria MITU*
}

\section{A LOOK AT THE CONCERNS SURROUNDING THE PROVISIONS OF THE 1923 CONSTITUTION}

\begin{abstract}
After the Great Union, one of the concerns of the enlarged Romanian State was that of establishing a new Fundamental Law that would lay proper foundations for the country. The elite felt there were threats to be avoided or resolved, a fact that strongly determined the way in which many issues were discussed. In the complex socio-political context, a Constitutional Dilemma emerged. The end result was that the 1923 Constitution generally implemented the Liberals' view on Romania's future. The opposition remained consistent in layering options, even if they didn't counter the principles per se but rather the means through which some of them were imposed, including the manner of adoption for the Act itself. However, their main interest went towards the State's administrative system. By looking at the 1923 Constitution as well as other preliminary proposals and parliamentary discussions on the matter, we will try to determine conflicting or otherwise affined views on the way Romania was going to be organised as a State and its nation built after the war.
\end{abstract}

Keywords: Greater Romania, Constitution, nation-building, nation-state, centralisation.

Fundamental Laws can be divided into two categories - some are revolutionary, meaning they substantiate the creation of a State or the shift between political systems, and others are evolutionary, meaning they come out of the revision of anterior constitutional texts. Revolutionary Constitutions tend to be conservative, keeping with a political or ideological status quo, whereas evolutionary Constitutions tend to bring on transformation and progress. In

\footnotetext{
* Dunărea de Jos University of Galați; e-mail: oana.mitu@ @ugal.ro
} 
Romanian history, the Constitutions from 1866, 1938, 1948 and 1991 were revolutionary, and the ones from 1923, 1965 and 2003 evolutionary ${ }^{1}$.

A Constitutional text generally holds two complementary characters - it has both relative and particular parameters - and it needs to keep to them at the same time in order to be rightful. Its relative character means that it contains elements of substance that are common to the entire human society, universally accepted notions, values, and principles that define the general level of spiritual, cultural and political development of the world contemporary to the elaboration of the constitutional text. In this respect, a Constitution must be "in compliance with the social experience of the time" ${ }^{2}$. Simultaneously, it must keep to its relative character, meaning that it should pursue the individuality of the nation, its special and inherent life conditions, thus be adapted to the "social experience specific to the nation"3. Every constitutional text reflects the vision and the interests of the political leadership (in a broader sense) at a certain moment. Moreover, Fundamental Laws contribute to the formation or the strengthening of social practices ${ }^{4}$. In this sense, when analysing the complex socio-political process that is nation-building, a very important element to follow is the manner in which lawmakers constitutionally define items such as national identity, culture, education, minority, majority, etc.

At the end of the Great War, Europe - and especially its Eastern corners needed to re-establish its grounds in order to adapt to new realities and to create foundations for a stable future. After the struggle for releasing its peoples from imperial subjections, the objective, as it had been the drive of the conflict, was to obtain nation-States. Contrary to the artificial bounds of before, these socio-political entities wanted to be based on natural affiliation. This implied an ethnic view on the notion of nation, but imperial colonial policies meant that this was far from achievable. Some States did not only have a large percentage of minorities within their boundaries, but also their own ethnics had been strongly affected by living under foreign rules (both instances being the case for Romania). The new and troublesome pursuit was building unitary national consciences, achieved through democracy and liberal principles, as these were the values on which a "new Europe" had been founded. Governments had to obtain all of their people's will for a unitary socio-political organisation, having the option of choosing between consolidating an

\footnotetext{
${ }^{1}$ Florin Abraham, "«Celălalt» în constituționalismul românesc. Studiu asupra relației dintre majoritate și minoritătị" in Vasile Ciobanu, Sorin Radu (coord), Partide politice şi minorităţi naţionale din România în secolul XX, vol. III, Techno Media, Sibiu, 2008, p. 31.

${ }^{2}$ Dimitrie Gusti, "Cuvânt de deschidere" in Noua Constituție a României. 23 de prelegeri publice organizate de Institutul Social Român. Cu o anexă cuprinzând noile Constituții europene, Tiparul Cultura Națională, București, 1922, p. 3.

${ }^{3}$ Ibidem, p. 3.

${ }^{4}$ Florin Abraham, art. cit, p. 31.
} 
ethnic or a civic identification system. For the latter, the State had to firstly prove that it would offer and guarantee security, liberty and wellbeing ${ }^{5}$ for all its citizens, elementary requirements for creating the bond between them and its institutions. In achieving this, it would secure an equal response: regardless of their ethnobiological background, citizens would gradually become loyal and solidly joined together in accepting the same values and working towards the same goals. Before they could be accepted as pieces of the State's authority, moral institutions had to be remodelled so as to suit new realities. This meant reshaping Constitutional and organic laws, Culture and Education, Religion, Army, and so forth, themselves instruments for building national conscience.

After the Great Union, Romania required a transformation in which everything needed to be rethought. In these conditions, law-making stopped being an ordinary political act and instead took exceptional valences because the future of the State and of the nation itself were dependent on the manner in which legislators determined national principles, values, rights and obligations. All of these elements were mainly established in the first decade of the interwar period, a timeframe nicknamed as the "brătienist decade" because of the great influence that the Liberal Party (and the Brătianu family) had over governance.

The very first necessity was a legislative foundation that would define and guide the process of national building, the unity of the State needing to be reflected in the Constitution in the sense of the latter creating a juridical framework for the former. The importance of this endeavour, as well as the complex and tensioned socio-political medium in which it took place led to a constitutional dilemma. We will see that it didn't necessarily regard the character, the content or the structure of the new Fundamental Law (although these weren't in absolute accordance either); rather than analysing the complex process of building, consolidating, applying and maintaining the political regime in which it manifested itself, the constitutional problem was one concerning power and State governance ${ }^{6}$. For this reason, it was doubled by an administrative dispute which divided the political arena into those supporting centralism and those advocating for decentralisation.

The first practical problem was the origin of the text: did the Union automatically extend the Constitution of the Old Kingdom into the new provinces? Was it enough to adapt it by adding elements necessary to their integration? Or had the Union annulled the Law, thus demanding a completely new one? The last

\footnotetext{
${ }^{5}$ Dragoş Sdrobiş, "Trecutul ne este o ţară vecină" in Revista Cultura, nr. 332/July $21^{\text {st }} 2011$. (http://revistacultura.ro/nou/2011/07/trecutul-ne-este-o-tara-vecina/, accessed January $21^{\text {st }}$ 2017).

${ }^{6}$ Angela Banciu, Istoria vieții constituționale în România (1866-1991), Casa de Editură și Presă Șansa, București, 1996, pp. 45-46.
} 
situation was chosen as an answer, but not strictly for a juridical reason. Although voting the modification of the 1866 Constitution would have been easier and less time consuming, it wouldn't have satisfied the historic reasons that the political generation of the Union pursued. A new State - which Romania ultimately was after suffering through profound systemic and organic transformations ${ }^{7}$ - needed $a$ new Constitution $^{8}$. The very first observation that comes at hand is that the text which ended up being put into function was mostly made of articles from the 1866 Law anyway. But this issue can be explained: it was not the content of the articles that needed to be entirely new, what mattered was the way in which the text was introduced to Parliament; as such, it was important that it be voted as a unitary law and not in pieces, as it would have been as a modified legislative item. It was necessary that the Constitution be debated and sanctioned as a whole in the Chambers for its in integro legitimation to be the expression of the country's will towards unity ${ }^{9}$. Another way of looking at the decision is that the governing Liberal Party de facto decided for adopting a new law. The reactions to this were, as to be expected, mixed in nature and intensity: some called it a côu d'état, while others saw it as "a wise acknowledgement and an unwavering pursuit for the superior interests of the country"10.

The discussions over the new Constitution split parties between those interested in how it should be compiled and who had the right to do it, although the strongest political battle was mainly fought over the second question ${ }^{11}$. Two views formed. The first ${ }^{12}$ was realist in nature and considered the Constitution an expression of the strength ratio between the parties. The second had formed in the specific post-war conditions and in the light of the new liberal European principles

\footnotetext{
7 Vintilă I. Brătianu, "Nevoile Statului modern și Constituția României Mari" in Noua Constituție a României. 23 de prelegeri..., Tiparul Cultura Națională, București, 1922, p. 26. Although it is important to note that this "newness" did not concern the actual juridical status of the State. See Barbu Berceanu, Istoria constituțională a României în context internațional. Comentată juridic, Rosetti, București, 2003, p. 302.

${ }^{8}$ See the exposition of N.G. Popovici, the speaker for the Report and the Project of the new Constitution, in the Senate meeting of March $9^{\text {th }} 1922$ (Dezbaterile Senatului nr. 37/ 22 mart. 1923 apud Șerban Crăciunoiu, Dezbaterile Parlamentare. Oglindă a vieții politice din România în anii 1922-1926, Editura Sitech, Craiova, 1995, pp. 165-166).

${ }^{9}$ Also see Constantin Berariu, Noua Constituție a României. Reflexiuni și Anteproiect, Cernăuți, Institutul de Arte Grafice si Editura "Glasul Bucovinei”, 1922, p. 8.

${ }^{10}$ Ibidem, p. 11.

${ }^{11}$ Ion Ciupercă, Opoziție și putere în România anilor 1922-1928, Editura Universității «Al. I. Cuza», Iași, 1994, p. 79.

${ }^{12}$ Theorized by F. Lasalle in his works (Fundamentul Constituției and Despre Constituție). In specialty literature of the time, these ideas can also be found at P. Constantinescu-Iași in Reforma Constituției, Ștefan Zeletin in Forță și Constituție, Constantin Stere in Ante-proiect de Constituție. According to Ion Ciupercă, op. cit, p. 103, footnote 6 .
} 
and stated that all parties should contribute to the elaboration of an Act that was going to influence the existence and the actions of all ${ }^{13}$. The political battle concerning who and how will draft the new Law was fierce, the main opponents to the Liberals being the Peasants' Party and the National Romanian Party from Transylvania. The two emphasised the violent resistance that they would put in front of any of the Government's decisions, not recognising their legal validity. In turn, with the intention of clearing any obstacle in the way of the new legislation ${ }^{14}$, the Liberals acted in ways that could be construed as rascally. Although not by lack of attempt, a political force that could put enough pressure on the existing governance did not ultimately materialise ${ }^{15}$; therefore, by using the balance of power, the Liberal Party succeeded in leaving its print on the way the new Constitution was installed and on its contents. The extremely tense political situation and the declarations of the sides created in the mind of those in power the idea that, if the opposition would at any time come to govern, it would bring a strong discontinuance in State policy ${ }^{16}$ that would ultimately endanger the country's future. This is an explanation for the rigid attitude that the Liberals held for the most part of their time in rule. Most of the constructive energy was trapped between the Liberal Party's determination to not let anyone undermine its plans and the opposition's efforts to stand against them, both losing focus of the truly important matters at hand ${ }^{17}$.

Another issue concerned the principles that the Constitution would contain. All voices, however oppositional in other aspects, came together over 3 incipient items: national unity, a democratic evolution for the country and constitutional monarchy ${ }^{18}$. The basic principle that would govern State life was to be democratic equality for all, not only political but social, cultural and economic as well ${ }^{19}$. This was necessary seeing how the ethnic landscape was much more diverse, but it needed to be done while also strengthening a Romanian national character to which the State was "entitled in the light of the overwhelming majority of the Romanian kin" ${ }^{20}$. The context was truly complicated, and balance tricky to find. The different points of view and arguments are important to follow because they essentially show the manner in which the socio-political elite perceived, planned and afterwards put

\footnotetext{
${ }^{13}$ A view retrievable from contemporary press, but also from Nicolae Iorga's Ce a fost și ce este Constituția României. According to Ion Ciupercă, op. cit, p. 103, footnote 7.

${ }^{14}$ Ion Ciupercă, op. cit, p. 81.

${ }^{15}$ Ibidem, p. 79.

16 Ibidem, p. 84.

${ }^{17}$ Ibidem, p. 84.

${ }^{18}$ Ibidem, p. 74.

${ }^{19}$ Vintilă I. Brătianu, art. cit, p. 28.

${ }^{20}$ Ibidem, pp. 27-28.
} 
into practice these rights and obligations, with the constitutional text being a first step in the process.

When debates were ongoing, three constitutional projects were officially registered: one from the Liberal Party ${ }^{21}$, one from the Peasants' Party ${ }^{22}$ and one from the Chernivtsian Constitutional Law professor Constantin Berariu ${ }^{23}$. The National Romanian Party from Transylvania did not draw up an especial material, declaring that all of the principles it stood upon had been already asserted in Article 3 of the Alba-Iulia Declaration. The Transylvanian perspective will yet be promoted as a personal project by jurist Romul Boilă $\breve{24}^{24}$ Various points of view were also expressed in parliamentary debates, through party platforms, in the press or through publishing. There was an interest in sparking the public's attention and implication in the debates, therefore the Romanian Social Institute organised a series of public conferences and published the lectures ${ }^{25}$. The volume contained essays from esteemed intellectuals and politicians of a varied spectrum, each of them explaining their personal and professional point of view on what the Constitution should include. The book also enclosed all of the European Constitutions that had been adopted after the war, so that Romanians could compare and accept the principles that were being argued for their own country. The book and its contents were very important for the social component of the matter. First of all, civic conscience and the involvement of the population needed to be exercised - thus, it was a form of civic practice. Second of all, the governing elite needed social justification and

${ }^{21}$ Anteproiectul de Constituție întocmit de Cercul de studii al Partidului National Liberal, cu o expunere de principii de D. R. Ioanițescu, București, Biblioteca Cercului de studii PNL, 1921. Officially a product of the Party's Study Circle, but practically based on the massive contribution of Vintilă Brătianu, according to Loredana-Maria Ilin-Grozoiu, "Principles and regulations stipulated in the Constitution from 1923" in Revista de Științe Politice. Revue des Sciences Politiques, no. 51, 2016, Editura Universitaria Craiova, p. 85 (http://cepos.eu/pdf/RSP\%2051.pdf, accessed on June $3^{\text {rd } 2017) . ~}$

${ }^{22}$ Anteproiect de Constituție întocmit de secția de studii a Partidului Țărănesc, cu expunere de motive de C. Stere, București, Viața Românească S.A., Tipografia Universală, 1922. Stere is generally assigned the complete authorship of the document, according to Raisa Grecu, Valentina Coptileț, "Contribuția lui Constantin Stere la modernizarea instituțiilor naționale: Anteproiect de Constituție" in Revista Națională de Drept, liberanr. 6/ 2015, p. 18, footnotes $2 \& 3$.

${ }^{23}$ Constantin Berariu, op. cit.

24 Romul Boilă, Ante-proiect de Constituție pentru statul român întregit, cu o scurtă expunere de motive, Cluj, 1921. Republished in 1931 as Studiu asupra reorganizării statului român întregit. Cuprinde un anteproiect de Constituție cu o scurtă expunere de motive, Cluj, Tipografia Naţională.

25 See Noua Constituție a României. 23 de prelegeri publice organizate de Institutul Social Român. Cu o anexă cuprinzând noile Constituții europene, Tiparul Cultura Națională, București, 1922. 
support for their decisions; by seeing, comparing and understanding the similarities between the Romanian situation and that of other European countries, the population would accept future courses of action as suitable and appropriate choices. Beyond these aspects, the volume was a fairly good example of democratic debate, as it contained views from varied sections of political and cultural life.

As the Liberal Party was at the top of the political power pyramid, we will start with a look at its general views and argumentations ${ }^{26}$. Vintilă Brătianu thought that a party's duty was not only to seek power, but to build up the country and help create a "unified soul" for the new State. He created the main reservoir for the Liberal agenda, the Study Circle, a think-tank meant for organizing future governance policies, "a laboratory for all matters concerning State policy" with objectives that went towards resolving post-war unification problems. It had 6 major work sections, including a special Board for the Constitution, with all reports being discussed in the Committee for the guidance, unification and consolidation of Greater Romania ${ }^{27}$. In a Programme launched in 1921, the Liberals announced "a national and democratic politics of order, progress, justice and social fellowship" 28 . From their standpoint, there were certain principles to add at the philosophical foundation of the State and in the Constitution. First of all, the State itself had to be active, meaning it should be "handling and synthesising all aspects of communal needs" 29 . In this sense, the State would not have a solely political role, but an economic and cultural one as well. Therefore, the future Constitution had to be cultural in character, permitting State control over education and religious practice $^{30}$. This interference would not be an authoritarian one, but it would nonetheless mean that the State had the right to monitor and coordinate several aspects that were important to communal (i.e. national) life. This would respect the due liberties meant for each citizen's specific manifestations depending on his ethno-cultural background, but at the same time it would guarantee the constant preservation of State interests. Promising to give "to all Romanian citizens of any

\footnotetext{
${ }^{26}$ The presentation of the Liberal agenda does not, for the moment, contain the Foreproject for the Constitution, as this document is yet to be available to the author. However, we believe that the principles extracted from the currently available sources are the same as those advocated by the Liberals in the proposition.

${ }^{27}$ For more information see Ovidiu Buruiană, "Cercul de Studii al Partidului Naţional Liberal: practici politice şi mize simbolice în perioada interbelică" in Anuarul Institutului de Istorie ,A.D. Xenopol”, Iași, tom 48/2011, pp. 283-292.

${ }^{28}$ Apud Nicolae C. Nicolescu, Șefii de Stat și de Guvern ai României. 1859-2003. Mică enciclopedie, Editura Meronia, București, 2003, p. 215.

${ }^{29}$ Vintilă I. Brătianu, art. cit, p. 28.

${ }^{30}$ Ibidem, pp. 28-29.
} 
race, language and confession the cultural and religious rights proper to them" ${ }^{\prime 31}$, it is still important to note that the Liberals strongly identified themselves with the Romanian national-State and the Romanian supreme right to govern and control. They were cautious and defensive of these elements, saying that a strongly assertive statement of the unitary and national character of the State was required, seeing how "the Minorities' Treaty tried to weaken it" ${ }^{32}$. Any lesser attitude was seen as highly dangerous and unpatriotic. Even so, Liberals considered that this assertiveness did not impede rightful living conditions for the population with different cultural characteristics, and that the State could easily afford liberal politics concerning minority rights because Romanians had "an overwhelming majority", because the minorities were not culturally unified, and because "the Romanian people have a great power of assimilation and national resistance" ${ }^{\prime 3}$. They would be wary of 2 criteria in their policies: that the unity and the interests of the State would be respected and that liberties given to minorities would not create an isolationist politico-cultural medium. They claimed brotherly relations with the minorities as a way to ensure the peaceful development of the country, but in practice the support for separate identity manifestations was acknowledged only for those minorities "that were faithful to the Romanian State" and that identified themselves with "the great State interests" ${ }^{34}$. Liberty is differently interpreted by applicant and receiver; this is why from some points of view this practice was construed as being hypocritical or even tyrannical, while for others it was a legitimate method of constructing a linear life for the national community. The Liberals ultimately wanted to strengthen the bonds between minorities and Romanians; they did not accept the idea of a forced assimilation (n.n. to be fair, they couldn't have legally applied such means anyway), but at the same time didn't allow the dissociation of interests between minorities and the State ${ }^{35}$. Overall integration was to be obtained by persuasion - a cultural alignment closely monitored by the authorities. Being the force that it was, education was the State's principal method of developing a national culture and, as Vintilă Brătianu said, this was one of the most important tasks of the post-Unification generation ${ }^{36}$. The specifics of the national education system had to be resolved primarily through the Constitution, and in it the

\footnotetext{
${ }^{31}$ Apud Bogdan Murgescu (coord), Istoria României în texte, Editura Corint, București, 2001, p. 298.

${ }^{32}$ Vintilă I. Brătianu, art. cit, pp. 27-28.

${ }^{33}$ Ibidem, p. 28.

${ }^{34}$ Ovidiu Buruiană, "Partidul Național Liberal și minoritarii etnici în România interbelică. Problema naționalismului liberal” în Vasile Ciobanu, Sorin Radu (coord), Partide politice şi minorităţi naţionale din România în secolul XX, vol. III, Techno Media, Sibiu, 2008, p. 113. ${ }^{35}$ Ibidem, p. 113.

${ }^{36}$ Vintilă I. Brătianu, art. cit, p. 30.
} 
fundamental principles were to be liberty, obligatoriness and gratuitousness and, most importantly, the State's absolute right to coordinate and verify all types and levels of schooling ${ }^{37}$. It was also its duty to do so, as the soul of the unschooled was more easily confused by agitations and made men accessible to antisocial and destructive ideas ${ }^{38}$. Thoroughly guiding all of its citizens' education was to be the State's way of protecting them and itself from ideological extremes and a path to forming national unity. The most significant problems were confession and language. Confessional and minority schools were generally seen as possible dangers to State authority, as they usually grew a strong and sometimes very hostile ethnic or minoritarian identity. The State would not support such units from its budget, especially confessional ones as schools had to be "instruments of scientific culture and laic aesthetics" 39 . The Liberal point of view was that religion-based units didn't serve a purpose in the modern world; therefore, they were to be nationalized and secularized ${ }^{40}$, and the Constitution had to firmly declare this fact. That is, religion wasn't to be altogether withdrawn, as moral formation was important; it was to become a provided right, an available option for students. Private schooling was to be permitted, having nonetheless to comply with official legislation and the State's sovereign right to inspect ${ }^{41}$. Therefore absolute freedom could not exist, even in virtue of the new liberal morals; "the provision that any person or corporation might open schools by their own unlimited will"42 would harm the State and the national sense of culture. All schools had to serve the fulfilment of "higher and permanent interests of the State and the (n.n. Romanian) kin". Thus private minoritarian schools were to constitutionally obtain existence only along with the requisite of compliance to the sort of education that would raise children "in the sense and spirit of the State" ${ }^{\text {"43 }}$. Subsequent organic laws were to indicate detailed regulations. For example, the disciplines considered to be crucial to the formation of a child's soul were usually the same ones that could also mould his national conscience (History, Geography, Romanian language and literature, Civic education); that is why they were to be taught exclusively in Romanian, and to deny this right was "to refuse the most elementary obligation that minorities have as

${ }^{37}$ I. Nistor, "Învățământul în viitoarea Constituție" in Noua Constituție a României..., pp. 366-367.

${ }^{38}$ Ibidem, p. 366.

${ }^{39}$ Ibidem, p. 369.

${ }^{40}$ Ibidem, p. 370.

${ }^{41}$ I. Mateiu, Minoritățile etnice din România și Legea învățământului particular. Discurs rostit în ședința de la 15 Decemvrie 1925 a Adunării Deputaților, Imprimeria Statului, București, 1926, pp. 6-12.

${ }^{42}$ I. Nistor, art. cit, p. 366.

${ }^{43}$ Ibidem, pp. 367-368. 
citizens of the State" ${ }^{44}$. Minorities would have the right of learning in their mothertongue all other disciplines; what was left were mainly sciences, not seen as dangerous to the national plan if taught in ethnic languages because they had no bearing on the inner livelihood of the children. Primary schooling in their specific language was a Constitutional right and the State had the duty of securing it. Its responsibility ended there; for secondary education minorities could open private units, but at their own expense and keeping with the aforementioned rules ${ }^{45}$.

Overall, education would concentrate on having a civic character and cultivating a sense of acceptance and solidarity. Propaganda of any kind -religious or political- was not to be tolerated. This being said, it is interesting to look at where the propaganda line was drawn. The State itself was undertaking a strong cultural propaganda programme that was Romanian in character. All in all, it had the historical moment as well as the power balance arguments; the newly formed Romanian State was stronger than its former opponents and it was in charge, thus having the right to take all necessary (democratic) measures to ensure its own consolidation.

The Liberals argued the "monitored liberty"-method not only for education, but for religious practice as well. It was thought that civic solidarity could only be gained from minorities by respecting their religious needs, at the same time paying close attention that underneath this liberty "there wouldn't be actions directed against the State and that citizens' souls wouldn't be made adversary towards the country to which their fate is bound" 46 . The Constitution was to reflect the right to practice one's religion not only "for modern reasons", but also "from the tolerant nature of Romanians", a not-so-disguised manner of saying that now that they were in power in territories where they were once oppressed, Romanians would take the high moral road and be generous in dealing rights and liberties ${ }^{47}$. Nevertheless, the dominant Church would be that of the Romanians - The Orthodox denomination named "National Church" and given an active role in the conscience-building process "by the virtue of past and future beneficial moral effects" 48 . Brotherly cooperation was to be established with the other National Church, the GrecoCatholic branch, the latter being thusly named only "from the security of the

\footnotetext{
${ }^{44}$ I. Mateiu, op. cit, p. 11.

${ }^{45}$ I. Nistor, art. cit, pp. 371-372.

46 Vintilă I. Brătianu, art. cit, p. 29.

${ }^{47}$ Or, as Cezar Petrescu said in his well-known work, Cei trei regi (The three kings), "for once more to prove the way in which we know how to forgive and forget after we have won". See Cezar Petrescu, Cei trei regi, ed. III cu o cronologie istorică de Ioan Scurtu, Editura Rai, București, f.a., p. 114.

${ }^{48}$ Ibidem, p. 30.
} 
orthodox position" ${ }^{\prime 49}$. This last aspect as well as the idea of national Churches in itself came into rational contradiction with the Constitutional right for equality between all citizens. This issue was noticed by the Transylvanian opposition, and jurist Romul Boilă (both in his 1921 project as well as in a 1931 revival) said that the matter was unlawful and that if the State wanted to support the Romanian kin's religious characteristics it could do so naturally, without a special constitutional disposition, by valuing the bigger number of Orthodox believers ${ }^{50}$. He demanded that the "confessional matter" be immediately untied so as to harness the influential power of the Churches in favour of the State ${ }^{51}$. In this sense, the opinion of Transylvanians and the opinion of Liberals from the Old Kingdom were similar - all believed religious sentiment should guide citizens towards patriotism as "a primordial duty". The difference was that the former seemed to believe this would happen naturally and ingenuously, while the latter had a more cynical and circumspect approach towards the positive intent of some confessions to serve State interests for an orthodox Romanian majority. Such an important aspect to the formation of a Romanian national culture wouldn't be left at the hands of "free market competition". What the Liberals offered was moral equality and freedom for religious practice, but not parity in what concerned the power that Church had on the formation of the spirit. Just as in the case of education, this was not going to be left to chance. In the propositions made by the Liberals (which ultimately were put into practice) we can clearly see the lines of targeted structuring, with others sharing the opinion ${ }^{52}$.

The constitutional propositions highlighted cultural differences in social thinking and political action. Accustomed to multicultural interactions, some were more open towards granting larger cultural liberties. Others wanted to assure the success of State policies by carefully controlling everything and therefore taking no risks with the outcome. Although all had the same objective in mind - the consolidation of a Romanian national State - and the same interpretation of instruments to be used, views on specific policies were mixed. The Peasants' Party, for example, concentrated on raising the general life conditions of the Romanian

\footnotetext{
${ }^{49}$ Ibidem, p. 30.

${ }^{50}$ See the motivation for Art. 18 in Romul Boilă, Studiu asupra reorganizării statului român intregit...,1931, p. 6 (http://www.provincia.ro/cikk_roman/c000027.html, accessed January $21^{\text {st }}$ 2017).

51 Romul Boilă, "Principiile Constituției Noi" in Noua Constituție a României. 23 de prelegeri publice organizate de Institutul Social Român. Cu o anexă cuprinzând noile Constituții europene, Tiparul Cultura Națională, București, 1922, p. 385 . Also see Art. 182 of Romul Boilă, Studiu asupra reorganizării....

${ }^{52}$ Constantin Berariu also stated that the Orthodox church is the State's dominant religious institution. See Noua Constituție..., 1922, Art. 16, Al. 4.
} 
peasantry, so a constitutional structure than would guide Romanian development did not raise important opposition from them; they targeted principles that would bring economic and social improvements to rural life.

The main opponent of the Liberal method was the National Romanian Party. The political battle between the two came from different views on the range and implementation of cardinal civic rights, but mostly from strongly different interests in what concerned State governance. The Transylvanians also thought that education should be a principal concern for the future nation-building process because "a national education, held at moral and patriotic height, is the guarantee for the future of the State" ${ }^{53}$, but did not agree with the exclusive patronage of the State. Instead, they supported collaboration between "all cultural forces" $" 54$. They more or less agreed with Liberal views on education and schooling, although being a bit more permissive. The most important difference is that schooling was to be adapted to a proposed decentralised administration, every province receiving the right to establish its own system of public education ${ }^{55}$. Another matter that they advocated was giving a constitutional right to minorities to largely use their own language in public life. Liberals agreed, but their discourse was a touch more reserved on the extent of constitutional mirroring of this right. Iuliu Maniu, the leader of the National Party, consistently defended the purely Romanian character of the national State, as per the general view. He also argued for a schooling system "impregnated by the Romanian mind, tradition and aspiration", a cultural system based on the heavily promoted Romanian art and literature, and an Army organised so as to be "the embodiment of national unification" (i.e. a Romanian army) ${ }^{56}$. Although both sides generally had a similar message concerning the relation between State and minorities - protecting national character, unity and integrity, an unhindered endurance of Romanian national spirit, preventing the corruption of Romanian characteristics, all of these while also giving respect to the individuality of other communities $^{57}$ - Liberals perceived Nationals as being too relaxed in their views and, funnily enough, sometimes too liberal, a fact that made them keep a constant distrusting eye on their propositions.

In his constitutional project, the Bukovinan professor Constantin Berariu upheld the liberal principles of combining individual liberties with the greater

\footnotetext{
${ }^{53}$ Romul Boilă, art.cit, p. 386.

${ }^{54}$ See the motivation for Art. 184 of Romul Boilă's Studiu asupra reorganizării..., p. 10.

55 See Art. 17 in Romul Boilă, op. cit.

${ }^{56}$ Iuliu Maniu, Problema minorităților. Conferință ținută la fundația Universitară Carol I în ziua de 11 Маіи 1924, Extras din volumul Politica externă a României, Institutul Social Român, Tiparul Cultura Națională, București, 1924, pp. 12-13.

${ }^{57}$ Ibidem, pp. 2-3.
} 
interests of the community. This meant that some collective liberties (education, religion, meetings and association) must, without being restrained or minimized, be kept in a proper guarantee with the interests and safety of the State ${ }^{58}$. A very interesting matter is that Berariu directly indicated a political Romanian nation; in doing so, he is one of few to state the civic character of the nation in the content of a potential constitutional text (Romul Boilă also referred to "the modern theory on the notion of State", but he did not use a political way of phrasing the definition). Berariu said he was moderate democratic, trying to hold a steady line between civic rights and obligations. For example, he proposed that citizens may use their own mother-tongues in relation to authorities in administrative units where they were dominant in number" 5 , but that "the establishment of Romanian as the official language of the State obliges all citizens to not be able to refuse under any circumstances official documents addressed to them in Romanian; they will not be able to defend themselves by invoking the ignorance of laws published in the Romanian language" ${ }^{60}$. Berariu's project was essentially a mix of personal ideas and items taken from the Liberal and Transylvanian propositions. The main difference between the three was the administrative organisation of the State. Generally, Berariu was a supporter of the Liberal constitutional project, but he did not agree with their view on administration. He said the same about the Transylvanian project of Romul Boilă, which he saw as good in many issues but overall too individualist, not sufficiently taking into account the need for a more modern social approach.

Thusly, we get to the main reason for political dispute concerning the provisions of the future Constitution - the issue of administration. If other aspects were more or less debatable, this one stood at the base of the most vicious political arguments, every party having a very distinctive opinion. On one side, the Liberals did not, by any circumstances, intend to renounce the heavily centralist French ${ }^{61}$

\footnotetext{
${ }^{58}$ Constantin Berariu, Noua Constituție..., p. 17.

${ }^{59}$ Ibidem, see Art. 32.

${ }^{60}$ Ibidem, see Art. 36.

${ }^{61}$ France wasn't the only example used for the construction of the interwar Romanian State. The second was Italy, where the central province (Piemont) coordinated the nation-State building process in a centralised manner. Italy had many similarities with the Romanian case, having to integrate provinces with different political, historical and cultural backgrounds which were more or less hostile towards assimilation. Ever since 1920 Romanian authorities kept in constant contact with their Italian counterparts, sending specialists for research and receiving notices concerning different policies. Apud Bogdan Dumitru, "Centralism or autonomy? The debate regarding the administrative organization in Romania between 1918 and 1925" in Studia Universitatis Babes-Bolyai-Studia Europaea, 2012(https://www.thefreelibrary.com/Centralism+or+autonomy\%3f+The+debate+regarding +the+administrative...-a0296255108, accessed June $4^{\text {th }}$ 2017). Also see Petre Andrei, Opera
} 
model that the Old Kingdom had been using and which had always ignored subsidiarity ${ }^{62}$. On the other side, representatives of the provinces inclined to plead for various forms of detachment from this heavily burdened system, but had no success in anything more than making the Liberals look at them with untrusting eyes. Although circumstances led to the ultimate implementation of what some called "the exclusive emanation of one party alone" ${ }^{63}$, the opposition remained consistent in arguing the necessity for changing the system. If previous to the Union the concentrated character of the administration did not inconvenience the development of the Kingdom, post-war voices denounced the need for changes, and giving Romanian statalism fresh foundations was argued as an imperative in the new political, economic and social conditions. In the middle of Constitutional deliberations, the idea of relaxing governing methods was supported by many voices from the Old Kingdom and from the provinces alike. There was more than one reason for this. Some considerations pointed at the character of the newly effected Union, constantly reminding that it had been freely done - transplanting governing principles from the Old Kingdom thus being out of the question as the provinces had not been conquered - and that "the union of spirit and senses" should not be confused with "unification" or "mechanical levelling"64. Each of the provinces had its own Constitutional tradition, and undermining them would reflect a nondemocratic, tyrannical governance ${ }^{65}$ which would defy the very same principles that the State pursued. Practically speaking, it was said that applying centralist principles would also be non-legal, as the system of the Kingdom was out of date ${ }^{66}$ and therefore extremely damaging. Finally, it was said that a true Union could only be realised by respecting particularities, and that its power stood in the freedom of diversity; disavowing objective differences would stir such discontent from citizens

Omnia, ediție realizată de Cătălin Bordeianu și Doru Tompea, Tomul VI, Vol. I, Partea I, Discursuri Parlamentare (1929-1933), Tipo Moldova, Iași, 2010, p. 493.

${ }^{62}$ Alexandru Zub, Un imperativ: Descentralizarea statală (http://convorbiriliterare.dntis.ro/ZUBmar8.html, accessed January 20 ${ }^{\text {th }}$ 2017).

${ }^{63}$ Romul Boilă, Studiu asupra reorganizării..., p. 2.

${ }^{64}$ Arguments from the Foreproject of the Peasants' Party apud Bogdan Dumitru, "Federalism and regionalism in Romanian political thinking in the interwar period" in Studia Universitatis Babes-Bolyai-Studia Europaea, LVII, nr. 1/2012, p. 25.

${ }^{65}$ Loredana-Maria Ilin-Grozoiu, art. cit, p. 86. Also see Anibal Teodorescu, "Viitoarea organizare administrativă" in Noua Constituție a României. 23 de prelegeri publice organizate de Institutul Social Român. Cu o anexă cuprinzând noile Constituții europene, Tiparul Cultura Națională, București, 1922, p. 287.

${ }^{66}$ See Anibal Teodorescu, art. cit, p. 287, but also G. Grigorovici, "Constituția sovietică și Constituția democratică” in Noua Constituție a României. 23 de prelegeri publice organizate de Institutul Social Român. Cu o anexă cuprinzând noile Constituții europene, Tiparul Cultura Națională, București, 1922, p. 69. 
that it would endanger the State's very existence by losing the social solidarity that people, paradoxically, felt under foreign dominations ${ }^{67}$. This was the manner in which the main argument of the Liberals (that decentralisation would encourage centrifugal tendencies ${ }^{68}$ and would ultimately lead to the dismembering of the State) was counterbalanced. On the other side, the governing Liberals proved to be extremely defensive, keeping to invoking the danger of destabilising the State ${ }^{69}$.

The proponents of administrative restructuring argued a better overall functioning for the State if governance was more closely acquainted with regional/local needs. Through Romul Boilă, the Transylvanians asked for decentralisation and local autonomy ${ }^{70}$, "without the intent of altering the unity and the indivisibility of the State" ${ }^{71}$. These would be contained in the moral and political figures of the King, the State Council (a replacement for the Parliament) and the Central Government, which would rule on matters directly concerning the existence of the country and its intrinsic characteristics: foreign affairs, the army, communications and transport, security, general economy, civil documents, rules of admittance in public structures, penal/civil/commercial procedures, etc. All other matters of public life would be controlled by provincial entities: legislated by Dietas and applied by provincial Governments. Thirteen years after the Union and ten years after his first proposal, Boilă still strongly supported this structure, saying that poor governance had led to the endangerment of vital State elements. But remaining at the start of the 1920s, his model was partially accepted and partially criticised by Constantin Berariu. He proposed a different type of decentralisation, based on organic diversification in the exercise of sovereignty, separating entities by their attributions: the King, the Legislative power, the ministers, the central and peripheral (de-concentrated) administration, the decentralised public administration, Finances, the Army, Ordinary justice, Administrative justice. This separation didn't mean isolation of parts, but cooperation for assuring collective interests and protecting individual ones ${ }^{72}$. He considered that central authorities were overweighted with minor requests that blocked the system and could have easily been dealt with at a regional level. He did not support autonomy or federalism, but instead thought that an efficient regional administration would silence those voices

\footnotetext{
${ }^{67}$ Arguments from the Foreproject of the Peasants' Party apud Bogdan Dumitru, "Federalism and regionalism...", pp. 24-25.

${ }^{68}$ Bogdan Dumitru, art. cit, p. 28.

${ }^{69}$ Lucian Boia, Romania. Borderland of Europe, translated by James Christian Brown, Reaktion Books Ltd, London, 2001, p. 103.

${ }^{70}$ See Art. 142 of Romul Boilă's Studiu asupra reorganizării....

${ }^{71}$ Ibidem, p. 3.

${ }^{72}$ Constantin Berariu, op. cit, p. 15.
} 
that asked for such things $\mathrm{s}^{73}$. Constitutional decentralization was also demanded by the Peasantry Party, although they required it for sensibly different reasons - the desire to obtain a sort of labouring juridical coalition ${ }^{74}$.

The vehement obstacle in face of this issue was the central authorities' fear that yielding would later put them in a situation in which they permitted the dissolution of the country. The governing Liberals thought that the maintenance or, worse yet, the deepening of regional loyalties would bring about serious disservices to the process of integration, unification and standardisation ${ }^{75}$, affecting the juridical foundation of the State and obstructing the formation of a common conscience amongst citizens. Debates in the Senate concluded that "any pursuit for federalism and regionalism" will be fought by mentioning the fact that the State is unitary in the first article of the Constitution ${ }^{76}$. Although the provinces were incorporated gradually, the centralist administrative system was heavily used for integration. The State's indivisible unity and national interest were permanent arguments against relaxing vigilance on this issue $\mathrm{e}^{77}$, with any opponent proposals being considered as irredentist. Looking back, it can be said that decentralisation would have been unlikely applied in the post-Union historical context. Firstly, regionalising power was not a traditional political practice for the Kingdom, the province that guided the building of the State. It used the deeply centralised French model, any other form being "impossible to integrate in its fabric of legal tradition"78. Secondly, Romania would have needed an advanced civic maturity, which it did not yet have. Inside a stable nation (by the parameters of political organisation, but mostly by the strength of civic conscience) a well-grounded regional power can negotiate with the Centre and ask for privileges that can ultimately take to decentralisation or federalisation ${ }^{79}$. In such cases, this "split" can actually be a sign of strength and health for the State, because the attachment of the population to local institutions can bind it around a sentiment of constitutional patriotism ${ }^{80}$. The newly formed Romanian State was still far from fulfilling such conditions. Lastly, a very important factor was the Liberal belief that their doctrine was "the only idea of progress for the country".

\footnotetext{
${ }^{73}$ Ibidem, p. 27.

${ }^{74}$ Apud Raisa Grecu, Valentina Coptileț, art. cit, p. 20.

${ }^{75}$ Also see Bogdan Dumitru, "Centralism or autonomy?...".

${ }^{76}$ A. Lascarov-Moldovanu, Sergiu D. Ionescu, Constituțiunea României din 1923. Adnotată cu desbateri parlamentare și jurisprudențe, București, Editura Tipografiei Curierul Judiciar, 1925 , p. 7.

${ }^{77}$ Alexandru Zub, loc. cit.

${ }^{78}$ Ioan Stanomir, Libertate, lege și drept. O istorie a constituționalismului românesc, Polirom, Iași, 2005, p. 86.

${ }^{79}$ See Bogdan Dumitru, "Centralism or autonomy?...".

${ }^{80}$ Apud Ioan Stanomir, op. cit, p. 87.
} 
Turning attention onto actual Parliamentary debates over the Constitution, the project that went into consultation was the Liberal one. The discussions that surrounded its articles show what sparked the interest of the legislators. These can be divided into the importance of notions and the importance of practical elements.

Notion-wise, it was decided that constitutionally the State would be nothing but national. There were voices raised against this identification because it "didn't meet the actual situation"; the Fundamental Law was a juridical document and couldn't be sentimentally patriotic, it was said, because of the existence of other secular ethnic communities ${ }^{81}$. Even so, the majority decided for a State dominated by those "with the deepest roots and the largest possibilities for the future" 82 . After this, there was a rather tangled debate about the way in which persons would be named and whether it was better to call them Romanians or Romanian citizens. Some said that the name «Romanian» was in effect solely an ethnic nominative, and that putting anyone under that definition without them actually being so would be taking away their bio-cultural character, replacing it with another that meant nothing to them, and at the same time losing true meaning of "what was Romanian to Romanians" 83 . Both in the Senate and in the Chamber, the minorities shared this standpoint ${ }^{84}$, saying that the label of «Romanian» indicated a racial signification that "clearly implied the assimilation of all minorities and could serve as an impediment for those peoples that didn't wish and couldn't assimilate themselves" ${ }^{\prime 85}$. Their representatives acknowledged the State's right to ask for civic loyalty, which they would give, but it couldn't claim that they become Romanians culturally ${ }^{86}$. To all this, representatives of the governance responded by giving their own definitions: «Romanian» was in practice far more inclusive than «Romanian citizen» because citizenship was a juridical-political construct that needed multiple elements to function (such as the age of discretion for men and the right to vote) and, in this sense, constitutionally calling people simply as «Romanians» would actually mean giving them access to more rights and liberties (otherwise, women and children and other persons which did not have the right to vote would know restrictions to natural rights). Therefore, politicians completely separated the two notions, saying that a «citizen» was only the person that could fully execute his political rights and

\footnotetext{
${ }^{81}$ Argument of D. Ioanițescu. See A. Lascarov-Moldovanu, Sergiu D. Ionescu, op. cit, p. 11.

${ }^{82}$ Nicolae Iorga's intervention in the Chamber of Deputies regarding the first article of the Constitution which declared the character of the State. See Ibidem, p. 9.

${ }^{83}$ Nicolae Iorga in the Chamber of Deputies. See Ibidem, p. 9.

${ }^{84}$ See the rejected amendment of A. Schullerus in Ibidem, p. 19.

${ }^{85}$ Leiba Tzirelsohn in the Chamber of Deputies, see Ibidem, p. 20.

${ }^{86}$ See Artur Connerth in Ibidem, p. 21.
} 
obligations. In this view, citizenship was completely cut away from nationality, and women and children, for example, were not Romanian citizens, they were simply Romanians.

Another important aspect is that the Romanian language was, for the first time ever, indicated as the official language of the State (before the 1923 Act, this matter had only been implied) ${ }^{87}$. The moral primacy of the Romanian kin was also underlined through spiritual matters. Apart from the equality accredited to all recognized faiths, the Orthodox and the Greco-Catholic denominations were named to be Romanian Churches, with primacy given to the Orthodox denomination. This is the only situation in the 1923 Constitution in which Romanian ethnics are given priority before other citizens ${ }^{88}$. Many interventions were made in Parliament about this provision. Legislators explained that "to dominate" - the word used to portray the arrangement - did not mean "to subject" all other faiths and their organisations, but that it indicated a prevailing by numbers. Through the size of its community, the Romanian Orthodox Church had the right to be the State's official provider of religious service (e.g. for national festivities ${ }^{89}$ and for baptizing the members of the Royal Family). Beyond the number of believers, another argument was that the Orthodox Church didn't traditionally cause conflicts between its authority and the authority of the State (as the Catholic Church had historically proven to $\mathrm{do}^{90}$ ), but would act in collaboration and completion to it. In practice, the Orthodox Church was heavily used to promote Romanian national goals and implement the nationbuilding project. The legislators did not hide this fact, stating that it was the most powerful element for strengthening a people's unity, and that not using it at that very moment in which the country needed its power would be a serious mistake ${ }^{91}$. The B.O.R. (Biserica Ortodoxă Română / Romanian Orthodox Church) had several benefits and duties from this spiritual authority. Politically, it had the participation of Metropolitan Miron Cristea in the Regency. Socially, it infiltrated the Army, hospitals, orphanages, schools, penitentiaries, etc. Its mission was to promote all superior, religious and moral aspirations of the Romanian $\mathrm{kin}^{92}$. If one wishes to understand the importance that was given to the constitutional role of the Orthodox Church and the force of spirituality in the Romanian nation-building agenda, it is sufficient to look at the sheer length of the parliamentary discussions given to this

\footnotetext{
${ }^{87}$ Barbu Berceanu, op. cit, p. 511.

${ }^{88}$ Ibidem, p. 623.

${ }^{89}$ See the explanations given by C. G. Dissescu to Art. 22 in A. Lascarov-Moldovanu, Sergiu D. Ionescu, op. cit, p. 181.

${ }^{90}$ Aurel Morariu in Chamber debates for Art. 22, see Ibidem, pp. 190-194.

${ }^{91}$ Lazăr Triteanu in Ibidem, pp. 206-207.

${ }^{92}$ Barbu Berceanu, op. cit, p. 623; also see footnote 6.
} 
subject as opposed to the issue of, say, education, which was another very important instrument.

The attention for securing State conveniences can also be seen in what regarded a general right - the liberty of expression. Although a modern and democratic attitude meant giving complete liberties to the press, some were denouncing the possibility of severe damages to State interests. The freedom to slander anyone and anything had implications in public morality and in the education of the population; it would especially have disastrous effects on the uneducated minds of the peasants ${ }^{93}$. But even with these perils looming over the smooth application of State plans, the principle was kept untouched.

In practical matters, the new Fundamental Law had some very important characteristics that made it evolutionary. First of all, although property remained inviolable, it was no longer intangible and sacrosanct and was instead submitted to the new concept of social utility. This ultimately meant that it became a social function, a notion applied to all individual liberties and rights, which were no longer "selfish" in manifestation, but instead actively took part in the overall development of the national community. They had a role and a purpose beyond personal necessity. The opposition contested this constitutional registration of social utility. They said that it undoubtedly was a citizen's moral duty to contribute to collective needs, which every one of them would certainly perform without dictation, but that it could not be put into the Constitution as the Fundamental Law was not designed to sanction moral bonds ${ }^{94}$. This new nature of property would bring about strong civic and individual insecurity, they argued; nonetheless, by explaining their ideas and, most importantly, by numerical rule, Liberals kept the new spirit of property in the Constitution. A second issue is that State intervention became a constitutional principle. This interventionism applied in all matters concerning communal life, including work and production (intervention for preventing economic or social conflicts). A third aspect joint together these two principles - the subsoil was nationalized, meaning that the most relevant resources were now the property of the State and, by relation, of the nation.

The importance of State instruments was also discussed and legislated. Education and schooling was one factor. Politicians asked for the clear and precise statement of 2 principles: that instruction is the State's business, pertaining to public administration, and that private schools can only function as an exception and in compliance with State rules and under its control. Then, the value of administration

\footnotetext{
93 See the interventions of I. Păcurariu and N.G. Popovici in Senate debates in A. LascarovMoldovanu, Sergiu D. Ionescu, op. cit, pp. 232-233.

${ }^{94}$ See the intervention of G. Trifon on Art. 17 in the Chamber of Deputies' debates.
} 
in the nation-building process came into attention. Civil servants were acknowledged as an "increase to national power" and pointed out as a major matter. As they were "destined to pass the spirit of lawfulness through their own conscience and then through the conscience of the masses and the entire country", they were used "by all cultural countries as the greatest force in building the State" 95 . The problem of the local councils' election was also raised, a part of the administration that was crucially important for the representation of State authority and interests at a regional level. Due to historical reasons (social, political and economic) the situation in the newly acquired provinces was that urban settlements were populated by a majority of ethnic minorities. This was correlated to the newly established system of universal voting, pointing out that an equal, direct, secret and mandatory vote would ultimately mean than in important urban areas communal councils would be almost entirely made up by other ethnics, making "the Romanian a stranger in his own country". In such a case, how could Romanians take back their cities, alienated in hostile times? If communes were "the cells of the State", what kind of a Romanian State would it be "when in those cells only strange blood would flow?" 96 Some were concerned that, instead of being a lever for the national and cultural development of Romanians ${ }^{97}$, urban life would come to stifle and supress rural Romanian life "and then the life of our State itself", and they were horrified that the Constitution was about to legislate this. Let the minorities have equal rights, giving them all possible freedom to culturally manifest and grow, but take the cities away from their grasp as a reflection of wise State governance. A 4-to-1 relation, grounded on the general statistic report of the country, would solve this problem, proponents said; legislators decisively rejected this option, as the will of the local numerical majority, however bothersome it would be to others, was rule.

The debates concerning the new Constitution's provisions mirror the tension in which the country lay at the completion of its territorial unification and the beginning of its socio-cultural consolidation. The extent and force of discussions show which of the principles and values were deemed more important for the nation-building process and emphasize the interests of each separate actor. At times, the difference between what was asked for and what was given can facilitate the understanding of future socio-political relations. Because of their political power the Liberals saw the implementation of their project with minor modifications. The

\footnotetext{
${ }^{95}$ G. Trifon discussing Art. 8 of the Constitution. See Ibidem, p. 74.

${ }^{96}$ Vasile Bianu in Senate debates over Art. 108. See Ibidem, pp. 425-426.

${ }^{97}$ V. Meruțiu in Chamber debates, see Ibidem, pp. 429-430.
} 
Constitution is essentially known to be the birth certificate of Neoliberalism ${ }^{98}$, the political philosophy that guided the first interwar decade in which the nationbuilding process knew its more pronounced period (or at least its first distinctive one).

The principles that stood as fundament to the new Constitution were fair and modern enough to be accepted and implemented by all political actors and to remain valid for 15 years (as official views later changed in relation to special local manifestations as well as broader European characteristics), beneficially influencing the Romanian society as it was reinventing itself. Individual freedoms and rights projected enough security for the progress of a modern democracy and of a civic sentiment, citizens developing trust based on the certainty of their right to be protected by the law ${ }^{99}$. The only element that continued to be denounced by the opposition was the centralised administrative organisation, looked upon as "an ostracising of brothers from the provinces and their exclusion from a normal and rightful validity to which all citizens should take part"; instead of cementing the longed-after unity, blood brothers suspected one another and bore grudges ${ }^{100}$. The fact that the main argument used either against or for administrative centralisation was portraying it as dangerous or beneficial to the formation of a true and strong national unity (depending on the political side from which it came from) is not surprising. Seeing how the binding of a common conscience amongst the population was the principal objective of the times and the main element of attention for the State, it was only natural that this would have been the go-to item for one to base his political position on.

The first interwar decade, ruled over by the Liberals, was haunted by their idea that a powerful discontinuity would affect State politics if parties from the opposition ever came to power. For this reason, although not exclusively, the building of Greater Romania took place inside a tense, strongly offensive-defensive medium, in which a string of voices motivated different visions of the future. The manner in which many elements were judged and applied was determined by the historical points in which Europe and Romania were at the time. The Country itself was responsible for its own future and the strength of its bonds was only going to be as lasting as the effort put into creating them. Looking to respect new modern principles of statesmanship, Romanian leaders also pursued anything that could misbalance their newly acquired statute. The 1923 Constitution maintained the

\footnotetext{
98 Political philosophy that arose after the war, in which Liberal foundations were reconstructed and supplemented with new views so as to better fit the new socio-political and economic realities.

${ }^{99}$ Angela Banciu, op. cit, p. 113.

${ }^{100}$ Romul Boilă, Studiu asupra reorganizării..., p. 3.
} 
pillars of the 1866 Act, then enriched it according to new needs, not only reflecting an European spirit of the age, but also the uncertainty of a country that still felt the menaces of internal and/or external threats ${ }^{101}$. It brought capital modifications to concepts important for the nature and the manifestations of the Romanian nation. One can read the plan for national (and nation-) building between its lines. It offered the ideological structure necessary for the formation of a unitary community. The State took on the responsibility of being an active participant in its own life, a right through which it regulated its own existence. Thusly, it became a builder, creating its own structures, operating through moral institutions (such as the Monarchy ${ }^{102}$, Justice, School, Army, and Church) which brought an essential contribution to the design of a mental community. The simultaneous provision of needs for both State and citizen was the main socio-political objective, one of its desired effects being that the people would develop civic loyalty and a sense of belonging regardless of biological characteristics. Individual approval and the will to contribute to the fulfilment of common interests were internal dispositions that needed to be born out of free personal conviction. Therefore, it was required that the instruments used by the State target the spirit. These had strong Romanian cultural characteristics and operated alongside pockets of other ethnic cultures, giving them democratic freedom but nonetheless looking to overpower and assimilate. Investments in cultural unification were strong, as this was the path chosen by the governants, a reality doubled by the fact that the Fundamental Law was never really accompanied by an ample program for sustainable development ${ }^{103}$.

\section{REFERENCES}

Abraham, Florin, “«Celălalt» în constituționalismul românesc. Studiu asupra relației dintre majoritate și minorități" in Vasile Ciobanu, Sorin Radu (coord), Partide politice şi minorităţi naţionale din România în secolul XX, vol. III, Techno Media, Sibiu, 2008, pp. 29-50.

Banciu, Angela, Istoria vieții constituționale în România (1866-1991), Casa de Editură și Presă Șansa, București, 1996.

Berariu, Constantin, Noua Constituție a României. Reflexiuni şi Anteproiect, Cernăuți, Institutul de Arte Grafice și Editura “Glasul Bucovinei”, 1922.

\footnotetext{
${ }^{101}$ Florin Abraham, art. cit, p. 32.

${ }^{102}$ The contribution of the Monarchy to the nation-building process can be seen in 2 separate elements: the constitutional monarchy governance system and the personal contribution of members of the Dynasty as individual symbols. The political elite unanimously supported the monarchic system and used King Ferdinand and Queen Mary as exponents of national unity.

${ }^{103}$ Angela Banciu, op. cit, p. 114.
} 
Berceanu, Barbu, Istoria constituțională a României în context internațional. Comentată juridic, Rosetti, București, 2003.

Boia, Lucian, Romania. Borderland of Europe, translated by James Christian Brown, Reaktion Books Ltd, London, 2001.

Boilă, Romul, "Principiile Constituției Noi" in Noua Constituție a României. 23 de prelegeri publice organizate de Institutul Social Român. Cu o anexă cuprinzând noile Constituții europene, Tiparul Cultura Națională, București, 1922, pp. 375-394.

Boilă, Romul, Studiu asupra reorganizării statului român întregit - cuprinde un anteproiect de Constituție cu o scurtă expunere de motive, Cluj, Tipografia Națională, 1931. (http://www.provincia.ro/cikk_roman/c000027.html, accessed January $21^{\text {st }}$ 2017).

Brătianu, Vintilă I., "Nevoile Statului modern și Constituția României Mari" in Noua Constituție a României. 23 de prelegeri publice organizate de Institutul Social Român. Cu o anexă cuprinzând noile Constituții europene, Tiparul Cultura Națională, București, 1922, pp. 25-38.

Buruiană, Ovidiu, "Cercul de Studii al Partidului Naţional Liberal: practici politice şi mize simbolice în perioada interbelică" in Anuarul Institutului de Istorie „A.D. Xenopol”, Iaşi, tom 48/2011, pp. 283-292.

Buruiană, Ovidiu, "Partidul Național Liberal și minoritarii etnici în România interbelică. Problema naționalismului liberal" in Vasile Ciobanu, Sorin Radu (coord), Partide politice şi minorităţi naţionale din România în secolul XX, vol. III, Techno Media, Sibiu, 2008, pp. 103-116.

Ciupercă, Ion, Opoziție și putere în România anilor 1922-1928, Editura Universității «Al. I. Cuza», Iași, 1994.

Crăciunoiu, Șerban, Dezbaterile Parlamentare. Oglindă a vieții politice din România în anii 1922-1926, Editura Sitech, Craiova, 1995.

Dumitru, Bogdan, "Centralism or autonomy? The debate regarding the administrative organization in Romania between 1918 and 1925" in Studia Universitatis Babes-Bolyai-Studia Europaea, 2012, pp. (https://www.thefreelibrary.com/Centralism+or+autonomy\%3f+The+debate +regarding+the+administrative...-a0296255108 , accessed June $4^{\text {th }} 2017$ ).

Dumitru, Bogdan, "Federalism and regionalism in Romanian political thinking in the interwar period" in Studia Universitatis Babes-Bolyai-Studia Europaea, LVII, nr. 1/2012, pp. 15-36.

Grecu, Raisa; Coptileț, Valentina, "Contribuția lui Constantin Stere la modernizarea instituțiilor naționale: Anteproiect de Constituție" in Revista Națională de Drept, liberanr. 6/ 2015, pp 18-20 (https://ibn.idsi.md/ro/vizualizare_articol/42151, accessed on June 3rd 2017).

Grigorovici, G., "Constituția sovietică și Constituția democratică" in Noua Constituție a României. 23 de prelegeri publice organizate de Institutul Social Român. Cu o anexă cuprinzând noile Constituții europene, Tiparul Cultura Națională, București, 1922, pp. 53-73. 
Gusti, Dimitrie, "Cuvânt de deschidere" in Noua Constituție a României. 23 de prelegeri publice organizate de Institutul Social Român. Cu o anexă cuprinzând noile Constituții europene, Tiparul Cultura Națională, București, 1922, pp. 1-24.

Ilin-Grozoiu, Loredana-Maria, "Principles and regulations stipulated in the Constitution from 1923" in Revista de Științe Politice. Revue des Sciences Politiques, no. 51, 2016, Editura Universitaria Craiova, pp. 83-93 (http://cepos.eu/pdf/RSP\%2051.pdf, accessed on June $3^{\text {rd } 2017) .}$

Lascarov-Moldovanu, A.; Ionescu, Sergiu D., Constituțiunea României din 1923. Adnotată cu desbateri parlamentare și jurisprudențe, București, Editura Tipografiei Curierul Judiciar, 1925.

Maniu, Iuliu, Problema minorităților. Conferință ținută la fundația Universitară Carol I în ziua de 11 Maiu 1924, Extras din volumul Politica externă a României, Institutul Social Român, Tiparul Cultura Națională, București, 1924.

Mateiu, I., Minoritățile etnice din România și Legea învățământului particular. Discurs rostit în ședința de la 15 Decemvrie 1925 a Adunării Deputaților, Imprimeria Statului, București, 1926.

Murgescu, Bogdan (coord), Istoria României în texte, Editura Corint, București, 2001.

Nicolescu, Nicolae C., Șefii de Stat și de Guvern ai României. 1859-2003. Mică enciclopedie, Editura Meronia, București, 2003.

Nistor, I., "Învățământul în viitoarea Constituție" in Noua Constituție a României. 23 de prelegeri publice organizate de Institutul Social Român. Cu o anexă cuprinzând noile Constituții europene, Tiparul Cultura Națională, București, 1922, pp. 365-374.

Sdrobiş, Dragoş, "Trecutul ne este o ţară vecină", Revista Cultura, nr. 332/ July $21^{\text {st }}$ 2011 (http://revistacultura.ro/nou/2011/07/trecutul-ne-este-o-tara-vecina/, accessed January $21^{\text {st }} 2017$ ).

Stanomir, Ioan, Libertate, lege și drept. O istorie a constituționalismului românesc, Polirom, Iași, 2005.

Teodorescu, Anibal, "Viitoarea organizare administrativă" in Noua Constituție a României. 23 de prelegeri publice organizate de Institutul Social Român. $\mathrm{Cu}$ o anexă cuprinzând noile Constituții europene, Tiparul Cultura Națională, București, 1922, pp. 285-295. 